NOTICE: this is the author's version of a work that was accepted for publication in Journal of Vocational

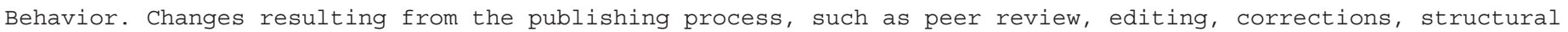

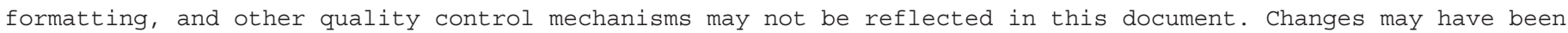
made to this work since it was submitted for publication. A definitive version was subsequently published in Journal of Vocational Behavior 79 (2011) 1,217-229 doi:10.1016/j.jvb.2011.01.004

\title{
Career adaptability, turnover and loyalty during organizational downsizing is
}

\author{
Ute-Christine Klehe ${ }^{\mathrm{a}, *}$, Jelena Zikic ${ }^{\mathrm{b}}$, Annelies E. M. Van Vianen ${ }^{\mathrm{a}}$, Irene E. De Pater ${ }^{\mathrm{a}}$ \\ a Work and Organizational Psychology, University of Amsterdam, Roetersstraat 15, 1018WB Amsterdam, The Netherlands \\ b School of Administrative Studies, York University, 4700 Keele Street, Toronto, Ontario, Canada M3J 1P3
}

\begin{abstract}
A B S T R A C T
During organizational restructuring and downsizing, employees often worry about being redundant, actually are redundant, and/or feel unsatisfied with their jobs. Employees, in turn, often react with poor loyalty to and high voluntary exit from the organization. The current study addresses this process from a careers' perspective, showing that career adaptability in the form of employees' career exploration and planning can account for at least some of these relationships. Redundancy fostered employees' career adaptive behaviors while job insecurity inhibited their career planning. Career planning, in turn, positively predicted employees' loyalty to the organization five months later while career exploration negatively predicted employees' loyalty, and positively predicted employees' exit reactions in the form of turnover intentions, job-search behaviors, and actual turnover. Implications and directions for future research are discussed.
\end{abstract}

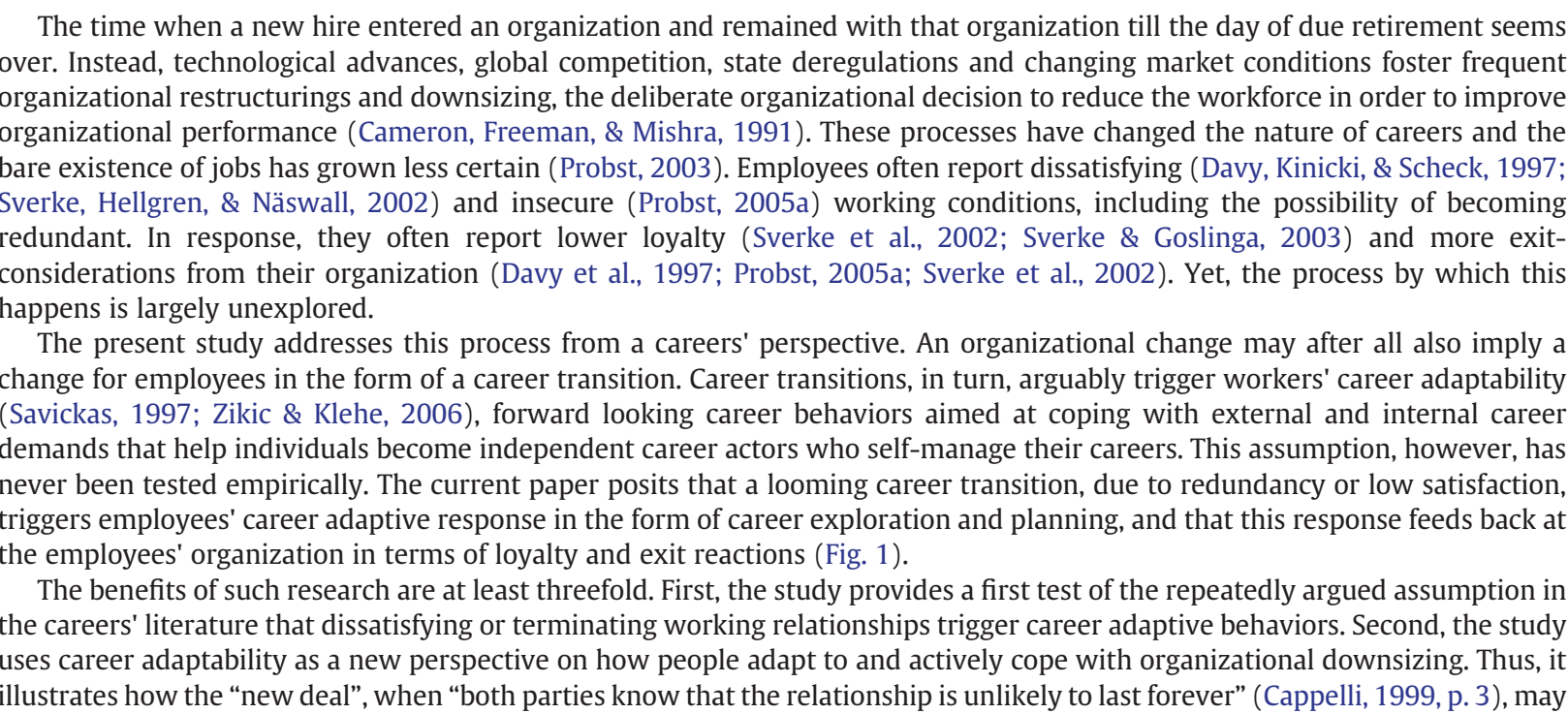

\footnotetext{
is Note. This research was supported by the FMG-UvA Research Priority Grant on Affect Regulation.

* Corresponding author.

E-mail address: u.klehe@uva.nl (U.-C. Klehe).
} 


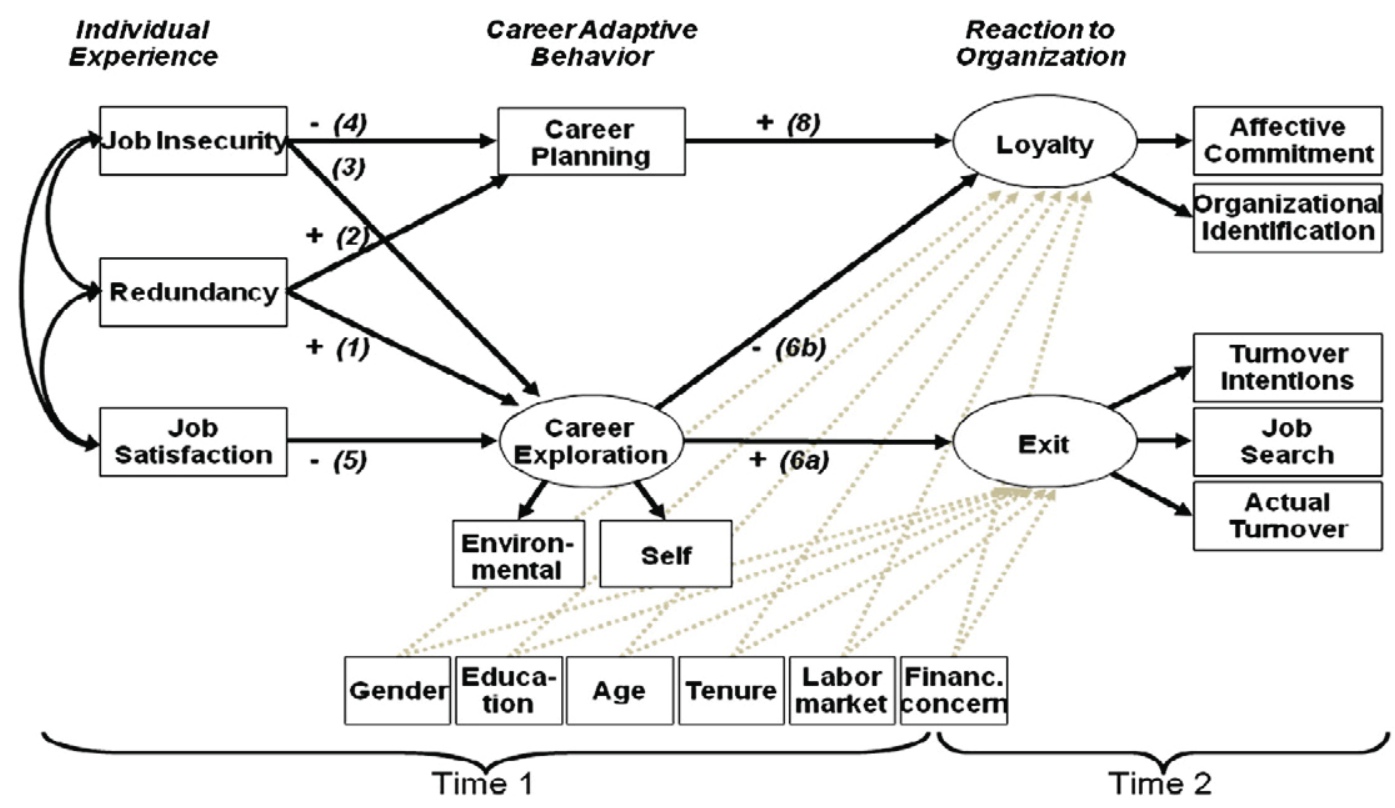

Fig. 1. Proposed model.

motivate employees to steer their careers not on the basis of organizational career trajectories but in accordance with their own plans, values and explorations (Hall, 2004). As a result, this study reveals how employees' career adaptability may link to their organizational loyalty and exit. Third, the study aims to explain some of the negative effects of job insecurity on organizational loyalty (Sverke \& Hellgren, 2000; Sverke et al., 2002) by considering the effect of job insecurity on employees' ability to plan their own careers. This study is one of the few two-wave studies in the job-insecurity literature (Sverke \& Hellgren, 2002). Such a design allows us to measure both employees' turnover intentions as well as their actual exit behavior.

In the following, we will outline the concept of career adaptability before showing how different individual experiences associated with organizational downsizing may trigger or inhibit employees' adaptive response, and how adaptability, in turn, may influence employees' loyalty and exit reactions toward the organization. Fig. 1 shows a depiction of the full proposed model.

\section{Career adaptability}

We all face career transitions, period[s] during which an individual objectively takes on a different role and/or subjectively changes orientation to a "role", at many stages of our lives (Latack \& Dozier, 1986; Louis, 1980). Career transitions require us to reevaluate our goals, attitudes, identity, and vocational routines (e.g., Ashforth \& Saks, 1995) and, thus, call upon our career adaptability, the "readiness to cope with the predictable tasks of preparing for and participating in the work role and with the unpredictable adjustments prompted by changes in work and working conditions" (Savickas, 1997, p. 254). Inherent in all models of career adaptability (Savickas, 1997, 2005; Super, Savickas, \& Super, 1996) is the notion that people need to make informed decisions about what they want and that they need to see a reasonable chance of getting there. Most prominent in helping people achieve this are the complementary behaviors of career exploration and planning.

Career exploration is the gathering of career related information about the environment or the self (Blustein, 1997; Stumpf, Colarelli, \& Hartman, 1983). Self exploration focuses on one's own interests, values, needs, skills, and experiences in order to reflect on one's career and to gain a deeper understanding of oneself. Environmental exploration is a person's investigation of various career options by collecting information on job opportunities and their work demands, organizations and their cultures, and occupations or industries, in order to make more informed career decisions. Self- and environmental exploration reflect parts of a common process aimed at establishing a suitable fit between the person and a potential environment (Parsons, 1909) and often go together since environmental exploration triggers reflections on one's interests, needs and abilities, whereas self exploration may initiate a more focused environmental exploratory strategy (e.g., Blustein, 1997; Flum \& Blustein, 2000; Stumpf et al., 1983). In combination, self- and environmental exploration allow people a deeper understanding of themselves and of their available options, by helping them examine how multiple opportunities fit with their values, desires, and career goals. And while career exploration does not necessarily imply a change in employment, it implies a wide focus that extends beyond a current employment situation. It may, thus, work as a tool to gain reorientation ('looking left and right') and to prepare a change and separation from the current situation. Past research has argued that exploration can be self-initiated or a reaction to an adverse or dissatisfying career situation (Blustein, 1997; Zikic \& Hall, 2009). Yet, no research has empirically tested these assumptions by comparing the exploration of redundant versus continuously employed employees.

Complementary to career exploration in nature, career planning refers to people outlining future career developments and setting and pursuing career goals (Gould, 1979). Since goals induce effort (Locke \& Latham, 1990) and since contemporary careers 
are characterized by lifelong planning, career planning is a good predictor of career success (e.g., Seibert, Crant, \& Kraimer, 1999). Career planning implies 'looking ahead', a long term future orientation aimed at promoting one's career path in general, whether this path is tied to a particular job or organization or not (Saks \& Ashforth, 2002). Career planning is arguably just as relevant during career transitions, though again, we lack empirical research on the effects of a looming career transition on employees' career planning.

\section{Career adaptability in the context of organizational restructuring}

The literature on career adaptability argues that career adaptability is important throughout one's career (Flum \& Blustein, 2000). It is mostly triggered by career transitions (Latack \& Dozier, 1986), including "the unpredictable adjustments prompted by changes in work and working conditions" (Savickas, 1997, p. 254). Yet, most studies focus on the school-to-work transition and only few studies have addressed career-adaptability among adults (Koen, Klehe, Van Vianen, Zikic, \& Nauta, 2010; Phillips, 1982; Zikic \& Klehe, 2006), none of them in the context of organizational change. This leaves fundamental assumptions of the career adaptability literature as of yet untested.

Judging from past research (Armstrong-Stassen, 2002; Probst, 2003), the most prominent experiences during organizational downsizing concern redundancy, job insecurity, and low satisfaction. In the following, we argue how redundancy should imply a looming career transition and, thus, instigate career exploration and planning. Job insecurity too might imply a transition, yet we assume the worry associated with insecurity to impair an adaptive response. Finally, career exploration should also increase when employees feel dissatisfied with their current jobs.

\section{Redundancy}

Job loss is the worst work-related life event we know about (Miller \& Rahe, 1997) and learning that one's job is redundant is about the worst news to receive during organizational downsizing. Redundancy entails that the person's job will soon be over and unless this person finds an alternative job within or outside of the organization within a specified time period, he or she will face layoff and possible unemployment (Armstrong-Stassen, 2002).

Redundancy should motivate employees to search for alternative employment elsewhere. Yet, settled employees with established roles, specialized skills and social networks in their current job are unlikely to do so right away (e.g., Hall, 1986; Zikic \& Hall, 2009). Rather, the first step in a mid-career move arguably entails reorienting oneself by exploring one's own interests, values, and options (Smart \& Peterson, 1997; Super et al., 1996). The practitioner literature, too, suggests that affected workers should "Survey and Recycle their D.A.T.A. (Desires, Abilities, Temperament, and Advantages)". ... "What do they really want at this point in their lives? What are they really good at? What kind of person are they and what kinds of situations make them the most productive and satisfied?", and, finally, "What advantages do they have, or what aspects of their life history or life situation could they turn into an advantage?" (Bridges, 1994, p. 76). In other words, affected employees should engage in career exploration. We propose:

Hypothesis 1. Redundancy will relate positively to career exploration.

Career theories suggest that career transitions foster career adaptive behaviors in general (Ashforth \& Saks, 1995; Blustein \& Phillips, 1988). A looming career transition like being redundant should impact not only employees' short-term career behaviors, such as their career exploration, but it should also trigger deeper and longer-term oriented adaptive cognitions, such as career planning. At the least, being redundant calls employees to prepare and to plan for an alternative career elsewhere and to "assess what to do next with their career" (Bridges, 1994, p. 76). At the same time, no research to date has actually tested whether the announcement of a career transition, that is, the knowledge that one is redundant, truly increases affected workers' engagement in career planning. We propose:

Hypothesis 2. Redundancy will relate positively to career planning.

Job insecurity

Another major experience and work stressor during downsizing is job insecurity, the worries and perceived powerlessness to maintain desired continuity in a threatened job situation (Gilboa, Shirom, Fried, \& Cooper, 2008; Sverke et al., 2002), especially if the downsizing process concerns a longer period of major reorganizations (as was the case in the current study). Redundancy and job insecurity share a number of characteristics (e.g., Probst, 2005b), yet they also meaningfully differ. Whereas redundancy and job loss are immediate events, job insecurity is an everyday experience involving prolonged uncertainty about the future (Sverke et al., 2002). And while both are undoubtedly stressful (Probst, 2005b), "job loss relieves at least one major source of stress-that of uncertainty” (Sverke et al., 2002, p. 243). Also, different from the objective fact of redundancy, job insecurity is an individual's subjective perception and interpretation of the immediate work environment. Here, we focus on the affective significance and concern about a possible job loss (De Witte, 1999). Such worries about a possible job loss may or may not be warranted by actual redundancy - and redundancy might not always cause concern (De Witte, 1999).

One might think that job insecurity should trigger the same career adaptive behaviors as being redundant. However, no past research has actually tested this assumption and studies on other dependent variables suggest the opposite effect. Job insecurity is 
characterized by a great fear of the future, high perceived powerlessness, and an external locus of control (Ashford, Lee, \& Bobko, 1989; Kinnunen, Mauno, Natti, \& Happonen, 1999). Job insecurity can ‘paralyze' employees (e.g., Gilboa et al., 2008), leaving them hanging in limbo for long periods. In general, a perceived lack of control reduces people's proneness to initiate action, such as their exploratory activities (Anderson \& Galinsky, 2006; Galinsky, Gruenfeld, \& Magee, 2003; Lammers, Galinsky, Gordijn, \& Otten, 2008). We propose:

Hypothesis 3. Job insecurity will relate negatively to career exploration.

In addition, a perceived lack of control also inhibits functioning on complex tasks, such as, for example, planning (Smith, Jostmann, Galinsky, \& van Dijk, 2008). Thus, the prolonged uncertainty inherent in job insecurity makes it difficult for employees to plan ahead (e.g., De Witte \& Näswall, 2003; Sverke et al., 2002). Consequently, we propose:

Hypothesis 4. Job insecurity will relate negatively to career planning.

Satisfaction

Organizational downsizing impacts many components of employees' lives, from stressful working conditions, increased workload, and role-ambiguities, to the loss of valued colleagues and career-opportunities. Such imbalance between desired and actual working conditions reduces job satisfaction, the cognitive, affective, and evaluative reactions to the job (Probst, 2003). Satisfaction may be particularly relevant in the study of career adaptability since low satisfaction may trigger career exploration but not necessarily planning: Planning focuses on one's long-term career path without being related to any particular job or organization (Saks \& Ashforth, 2002). Planning may be used just as much by satisfied employees interested in building on their current careers as it may be used by dissatisfied employees planning for a career outside of the current organization.

Career exploration, however, does imply the consideration of a change. Career exploration can be self-initiated in reaction to dissatisfying employment: "When individuals are able to act as agents in their own careers, they are often seeking to change some aspect of their current situation, and engaging in career exploration is a necessary step in this process" (Zikic \& Hall, 2009, p. 182). Smart and Peterson (1997) found that unsatisfied workers engaged in more career exploration. Hence, we assume that the more employees are dissatisfied with their current situation, the more they will explore both their own personal values and needs as well as the opportunities that might be available to them elsewhere (see also Shen \& Hall, 2009):

Hypothesis 5. Job satisfaction will relate negatively to employees' career exploration.

\section{Career adaptability and employees' reactions}

Many organizational downsizings follow "the premise that there really are only two ways to make money in business: either you cut costs or you increase revenues" (Cascio \& Wynn, 2004, p. 426). Yet, downsizings often create more trouble than good for the organization (Cascio, 1993, 2002; Cascio, Young, \& Morris, 1997). A possible reason may lie in negative employee reactions with exit and low organizational loyalty being most prominent (Sverke \& Goslinga, 2003). Indeed, Probst (2003) found that six months after the announcement of organizational restructuring, affected workers reported lower commitment and higher turnover intentions than they had held prior to the announcement. We believe that addressing employees' experience of the downsizing from a careers' perspective can help to explain these relationships.

\section{The effects of career exploration}

While no studies have tested the effects of career exploration during organizational downsizing, Werbel (2000) found that environmental exploration predicted the intensity with which university graduates sought for their first jobs. A similar reaction may happen among people who already hold a job. After all, exploration implies a wide focus and the active consideration of alternatives. It works as a tool to gain reorientation with regard to one's personal needs, interests, and values, but also with regard to the different types of jobs, organizations, and industries that might satisfy these needs (Blustein, 1997; Stumpf et al., 1983). Given that exploration leads to a consideration of more diverse employment options, over time the current organization should cease to hold a position as the only place that people envision themselves working at, allowing employees to both feel less bound by their current organization and to be more likely to exit. Thus, we assume that:

Hypothesis 6. Career exploration will positively predict employees' exit (6a) and will negatively predict their organizational loyalty reactions (6b).

The mediating role of career exploration

A subsequent question then is how much career exploration may account for the largely well-validated links between redundancy, job insecurity, and satisfaction on the one and loyalty versus exit on the other side (see Fig. 1). It is likely that redundant employees have to and that dissatisfied employees may want to reevaluate their aspirations and dreams, their strengths and weaknesses, and how well these might fit alternative employment. Exploring alternative types of positions or industries may further help them to separate themselves from the current employment and to move towards alternative 
employment. Furthermore, following up on our hypotheses 1, 3, and 5 (linking redundancy, job insecurity, and satisfaction to career exploration), and hypotheses $6 \mathrm{a}$ and $6 \mathrm{~b}$ (linking career exploration to exit and organizational loyalty), we propose that:

Hypothesis 7. Career exploration will mediate the link between redundancy, job insecurity, and satisfaction on the one, and loyalty and exit reactions on the other side.

\section{Effects of career planning}

The effect of career planning on organizational exit is unclear. On the one hand, if one assumes that employees undertake career planning in anticipation of a looming career transition, career planning might facilitate and prepare employees' exit from the organization. On the other hand, many employees also plan their careers within the course of their regular job, which in turn might imply career planning and exit to be largely independent from one another.

Planning allows employees to envision a possible future and, thus, to maintain a sense of control over their situation by directing their actions in line with their plans. The ability to conduct career planning is often based on one's previous employment history, and tenure in the current organization allowed for additional accumulation of human and social capital (Inkson \& Arthur, 2001), thus potentially increasing individuals' employability and allowing them to conduct more meaningful and effective future career planning; indirectly making them more loyal to this employer that has allowed them the opportunity to plan further. Thus, being able to plan and envision future career goals is an important predictor of employee loyalty to the organization (e.g., Jalonen, Virtanen, Vahtera, Elovainio, \& Kivimaki, 2006) with loyalty here being understood not as the opposite of exit but as positive attitudinal and emotional reactions to the organization. Being able to plan, even if it involves plans outside of the current organization, furthermore implies predictability and allows employees more options to adjust to the possibly new situation, thus raising perceptions of procedural justice which in turn would strengthen employee loyalty to the current organization (e.g., Turnley \& Feldman, 1999). Hence, we assume that being able to plan ahead will be positively related to employees' sense of loyalty to the organization.

Hypothesis 8. Career planning will positively relate to employees' organizational loyalty.

\section{Method \\ Organizational context}

This study was run in a recently privatized Dutch technical service organization undergoing strategic downsizing to reduce $17 \%$ of the workforce within three years while complying with legal regulations and acknowledging the organization's history with its up to then bureaucratic but safe employment policies. Downsizing happened via quarter-annually redundancy announcements. In order to reduce the number of layoffs, non-redundant employees, too, were encouraged to consider attrition. Thus, the information that one's job was redundant did not necessarily imply losing one's job (e.g., Armstrong-Stassen, 2002). Rather, redundant employees learned about their situation a full year before lay-off. During this year, employees could wait it out and hope for a sufficiently high attrition among their peers, could apply for a different job within the organization, or could make use of diverse outplacement services. Whenever redundancies prevailed after a year, employees would be employed for another half year with intensified outplacement assistance.

\section{Procedure}

Two questionnaires were sent to employees five months apart. About a month after one of the first layoff-announcements, a representative sample of 350 employees was contacted via HR-managers, an in-house job-fair organized for all employees, and intra-organizational e-mails to participate in an anonymous study organized by a university otherwise not affiliated with the organization (Time 1). Participants could respond online or on paper to questions that addressed control variables, job insecurity, redundancy, job satisfaction, career exploration, and career planning. Officially, the study's purpose was to learn about employees' views on the organization's people-management and change. A first call and a reminder produced 210 respondents (60\%). Five months later (Time 2), participants received a follow-up questionnaire to assess their current employment status, and, if they were still working for the organization, their loyalty and exit considerations. Five months should give respondents sufficient time to find new employment if they sought it (Wanberg, Hough, \& Song, 2002). Yet, we also wanted to ensure that no exits were due to layoffs and that redundant employees still faced a chance to stay with the organization (Armstrong-Stassen, 2002). After an initial call and a reminder, 105 participants (50\%) responded. Six had left the organization. Via the organization's internal address-book, we learned that 13 participants had left the organization in total. The resulting estimate for the annual turnover rate (14.9\%) is representative for the organization at that time overall but is also noteworthy for an organization where employees have traditionally worked for about 35 years at time of separation. 
Participants

Time 1

As is quite representative of the organization overall, $76 \%$ of the respondents were men. The average age was $43.26(S D=7.58)$ and the average tenure 17.39 years $(S D=9.16)$, a number in line with the history of this organization as a lifetime employer. Participants had undergone vocational training (37\%) or held a Bachelor's (37\%) or Master's degree (8\%). Some held a high school degree or basic training (18\%). Participants' worked in administrative (30\%), technical (27\%), managerial (17\%), technical sales (5\%), consultancy (5\%), or other jobs (27\%).

Time 2

Similar to Time 1,73\% of Time 2 respondents were men. The average age was $43.41(S D=7.76)$ and the average tenure 17.51 years $(S D=8.84)$. Participants had undergone vocational training $(35 \%)$ or held a Bachelor's $(41 \%)$ or Master's degree $(10 \%)$. Some held a high school or basic training degree (13\%). Participants' occupations included technical (20\%), administrative (34\%), consultancy (7\%), managerial (17\%), technical sales (5\%), or other (17\%). There were no demographical differences between Time 1 and Time 2 participants. Moreover, participants were quite representative of the organization's overall workforce.

Measures

Unless noted otherwise, items were answered on a Likert scale ranging from 1 (strongly disagree) to 5 (strongly agree).

Predictors

Redundancy was measured with one dichotomous item, asking participants whether they had obtained official information according to which their job was being redundant. Job insecurity was measured with Hellgren, Sverke, and Isaksson's (1999; e.g., "I am worried about having to leave my job before I would like to") three-item scale. Job satisfaction was measured with Smith, Kendall, and Hulin's (1969; e.g., "In general I am satisfied with my current job") three-item scale.

\section{Career adaptability}

Exploration was measured with Zikic and Klehe's (2006) version of Stumpf et al.'s (1983) scale, assessing self (5 items; e.g., "have been retrospective in thinking about my career") and environmental exploration (6 items; e.g., "sought more information on specific career options of interest to me") on a scale from 1 (a little) to 5 (a great deal). Planning was measured via Gould's (1979; e.g., "I have a strategy for achieving my career goals") six-item scale.

\section{Control variables}

We controlled for variables relevant to the turnover and job-search literatures (e.g., Griffeth, Hom, \& Gaertner, 2000; Kanfer, Wanberg, \& Kantrowitz, 2001), namely gender, tenure, age, level of education, financial concern (Ferman and Aiken's (1964) three-item scale), and perceived labor market demand (Wanberg et al.'s (2002) four-item scale). Controlling for the perceived labor market demand is especially important for this group as one's chances of reemployment may differ depending on other factors, such as different demand for certain occupations, skill type, and fewer opportunities in some geographic areas.

\section{Loyalty at Time 2}

To capture both the cognitive and emotional components of respondents' loyalty, we measured affective commitment and organizational identification (Landy \& Conte, 2004). Affective commitment, the "identification with, involvement in, and emotional attachment to the organization" (Allen \& Meyer, 1996, p. 253) was measured with Meyer, Allen, and Smith (1993) sixitem scale (e.g., "[name-of-organization] has a great deal of personal meaning for me"). Organizational identification, a form of social identification by which people define themselves via their membership in an organization (Ashforth \& Mael, 1989), reflects peoples' perceived congruence of individual and organizational values and the connection and feeling of oneness with or belonging to that organization (Saks \& Ashforth, 2002). It was measured with the six-item scale (Mael \& Tetrick, 1992; e.g., "When someone praises this organization, it feels like a personal compliment") endorsed most in the organizational identification literature (Riketta, 2005).

\section{Exit at Time 2}

The ultimate criterion for employee exit is turnover. Yet, turnover is a dichotomous variable of relatively rare occurrence. Hence, many studies measure turnover intentions, the "conscious and deliberate willfulness to leave the organization" (Tett \& Meyer, 1993, p. 262) and a direct predictor of actual turnover (Griffeth et al., 2000) whereas other studies focus on concrete turnover-related behaviors that employees undertake to find alternative employment (e.g., Lim, 1996; Sverke \& Hellgren, 2001). Job search, the active search for and pursuit of alternative job openings (Blau, 1994) is both a strong behavioral predictor of turnover (Griffeth et al., 2000) and of finding a new job elsewhere (Kanfer et al., 2001). The current study used all three indicators of exit: Turnover intentions were measured with a 3-item scale employed in earlier research (Saks \& Ashforth, 2002; Koen et al., 2010; e.g., "I frequently think of quitting my job"). Job search was examined with Wanberg et al.'s (2002) version of Blau's (1994) 13-item behavioral job-search measure (e.g., "used the Worldwide Web or other computer services to locate job openings"). Turnover was assessed by asking participants whether they were still working at or whether they had left the organization. Moreover, 
participants were looked up in the organization's internal address-book to see who had left the organization. None of these people had been forced to leave at this point in time due to layoff.

\section{Data analysis}

We tested our assumptions via structural equation modeling (SEM) in AMOS16, assessing model fit via $\chi^{2}$ and the ${ }^{\chi^{2}} / d f$ ratio, as well as with absolute (SRMR and RMSEA) and incremental fit indices (IFI and CFI). These indices are very sensitive to complex model misspecifications while being less sensitive to distribution and small sample sizes (Hu \& Bentler, 1999). We ran two sets of path analyses (Models A and B) based on maximum likelihood procedures. These procedures provide accurate parameter estimates with samples of about 100 participants and larger (Gerbing \& Anderson, 1985). In line with past findings, we included covariances between the antecedent variables (e.g., Sverke \& Hellgren, 2000). Model A, based on participants who had remained with the organization and had responded to both surveys (VV=99), served for the prediction of both loyalty and exit considerations at Time 2. Model B, based on all participants of Time $1(\mathrm{~N}=210)$, served to predict actual employee turnover at Time 2.

We tested hour hypotheses via a series of model comparisons (Mathieu \& Taylor, 2006): The saturated models $1_{\mathrm{A}}$ and $1_{\mathrm{B}}$ assumed the three predictors to predict the outcomes both directly and indirectly via participants' career adaptability behaviors. Such a saturated model should fit the data well and serves as a comparison against which to test the fit of more parsimonious models. The first of these models $\left(3_{\mathrm{A}}\right.$ and $\left.3_{\mathrm{B}}\right)$ test whether there is at all a need to include career planning and exploration as possible process variables by estimating direct relationships from predictors to outcome variables only with no paths leading to or stemming from career planning and exploration Finally, models $4_{\mathrm{A}}$ and $4_{\mathrm{B}}$ present the only indirect model proposed in the hypotheses and Fig. 1.

\section{Results}

Table 1 presents the descriptive and correlations between the studied variables. Confirmatory factor analyses (CFA) tested Time 1 and Time 2 measurement models. We followed the SEM-practice to create three parcels (i.e., subscales) for every construct measured with more than three items in order to reduce the ratio of estimated parameters to sample size (Hagtvet \& Nasser, 2004). The Time 1 measurement model $(n=210)$ assumed six factors (redundancy, job insecurity, satisfaction, planning, environmental and self exploration) with environmental and self-exploration loading onto a common second order exploration factor. Covariances existed between the three predictors redundancy, insecurity, and satisfaction and the two adaptability factors career planning and exploration. The model fit the data well with all factor loading being significant $(\mathrm{p}<.01$; average $\lambda=.81$; Table 2). The Time 2 measurement model $(n=99)$ assumed two covarying second order factors (loyalty and exit), each estimated via their respective first-order indicators (organizational identification and affective commitment versus turnover intentions and job search). This model, too, fit the data well with all factor loadings being significant $(\mathrm{p}<.01$; average $\lambda=.77$ ).

\section{Hypotheses testing}

Both saturated models $\left(1_{\mathrm{A}}\right.$ and $1_{\mathrm{B}}$ ) found rather mixed support, implying that $(\mathrm{a})$ these full models fail to include some relevant paths and/or that (b) the numerous non-significant paths between control- and outcome-variables reduce the models' degrees of freedom without accounting for any variance in the dependent variables (Table 2). Modification indices suggested that career exploration decreased with tenure and in Model $1_{\mathrm{A}}$ that redundant employees reported lower turnover intentions. Many redundant employees might see the turnover-decision taken out of their hands. Therefore, we created adjusted saturated models $\left(2_{\mathrm{A}}\right.$ and $2_{\mathrm{B}}$ ) including a path from tenure to career exploration and, in Model $2_{\mathrm{A}}$, from redundancy to turnover intentions. We also deleted small $(\gamma<.08)$ non-significant paths from the control variables. While improving the models' fit, these decisions impacted none of the focal relationships, such as the significant positive paths from redundancy to career planning and exploration, the significant negative paths from job insecurity to planning and from satisfaction to exploration, the significant positive paths from planning to loyalty and from exploration to exit, and the significant negative path from exploration to loyalty.

The adjusted models fit to the data well and served as the comparison models for later analyses. For comparison, the direct models $\left(3_{\mathrm{A}}\right.$ and $\left.3_{\mathrm{B}}\right)$ tested whether it was necessary to include career planning and exploration into the model. In Model $3_{\mathrm{A}}$, job satisfaction related negatively to exit and related positively to loyalty, beside two marginally significant relationships between redundancy and exit, and job insecurity and loyalty. In Model $3_{\mathrm{B}}$, low satisfaction and redundancy marginally predicted turnover. Yet, both models fit the data poorly, attesting that career planning and/or exploration contribute to the prediction of loyalty and exit.

The proposed indirect models $\left(4_{\mathrm{A}}\right.$ and $4_{\mathrm{B}}$ ) fit the data well and confirmed many proposed relationships (see Fig. 2): Redundant employees used more exploration and career planning (supporting Hypotheses 1 and 2), whereas job insecurity was negatively related to career planning, yet not to career exploration (supporting Hypothesis 4, but not 3). Satisfaction showed a strong negative link to career exploration (supporting Hypothesis 5). Career exploration was negatively and career planning was positively related to loyalty five months later (Model $4_{\mathrm{A}}$; supporting Hypotheses $6 \mathrm{~b}$ and 8 ). Also, career exploration was positively related to intended (Model $4_{A}$ ) and actual (Model $4_{B}$ ) exit from the organization (supporting Hypotheses 6a). As proposed in Hypothesis 7, career exploration fully mediated all effects of job satisfaction on loyalty $(\beta=.42$, Sobel $=3.87$, $p<.01)$ and exit intentions $(\beta=-.53$, Sobel $=-4.37, \mathrm{p}<.01)$, as well as the effect of both satisfaction $(\beta=-.07$, Sobel $=-2.10, \mathrm{p}=.04)$ and 
Table 1

Means, standard deviations, and correlations between the studied variables.

\begin{tabular}{|c|c|c|c|c|c|c|c|c|c|c|c|c|c|c|c|c|c|c|}
\hline & Mean & S.D. & 1 & 2 & 3 & 4 & 5 & 6 & 7 & 8 & 9 & 10 & 11 & 12 & 13 & 14 & 15 & 16 \\
\hline \multicolumn{19}{|l|}{ Time $1(n=210)$} \\
\hline \multicolumn{19}{|l|}{ Control variables } \\
\hline 1. Gender & 1.76 & .43 & - & & & & & & & & & & & & & & & \\
\hline 2. Education & 3.38 & .87 & .12 & - & & & & & & & & & & & & & & \\
\hline 3. Age & 43.44 & 7.61 & .18 & -.09 & - & & & & & & & & & & & & & \\
\hline 4. Tenure & 17.47 & 9.30 & .13 & -.24 & .65 & - & & & & & & & & & & & & \\
\hline 5. Perceived labor market & 2.84 & .75 & -.10 & .23 & -.28 & -.31 & $(.76)$ & & & & & & & & & & & \\
\hline 6. Financial concern & 2.44 & 1.06 & .02 & -.24 & .24 & .21 & -.22 & $(.82)$ & & & & & & & & & & \\
\hline \multicolumn{19}{|l|}{ Predictors } \\
\hline 7. Redundancy & .20 & .40 & -.01 & -.03 & .03 & .00 & -.04 & .08 & - & & & & & & & & & \\
\hline 8. Affective job insecurity & 3.72 & .94 & .17 & -.23 & .28 & .19 & -.40 & .31 & .25 & $(.81)$ & & & & & & & & \\
\hline 9. Job-satisfaction & 3.47 & .86 & .06 & -.02 & .08 & .04 & .03 & .02 & -.06 & .15 & (.78) & & & & & & & \\
\hline \multicolumn{19}{|l|}{ Career adaptability } \\
\hline 10. Career planning & 2.82 & .61 & -.12 & -.03 & .06 & -.02 & .13 & .13 & .20 & -.11 & -.08 & $(.76)$ & & & & & & \\
\hline 11. Exploration: Self & 2.76 & .99 & -.19 & .04 & -.15 & -.21 & .12 & .03 & .16 & -.08 & -.36 & .18 & $(.91)$ & & & & & \\
\hline 12. Exploration: Environmental & 2.11 & .83 & -.10 & .07 & -.04 & -.17 & .10 & .02 & .37 & -.01 & -.27 & .39 & .49 & (.89) & & & & \\
\hline \multicolumn{19}{|c|}{ Time $2(n=99$; except for actual turnover $n=210)$} \\
\hline 13. Org. identification & 3.26 & .70 & .10 & .08 & .19 & .27 & -.05 & -.02 & -.09 & -.02 & .39 & -.19 & -.29 & -.33 & $(.85)$ & & & \\
\hline 14. Affective commitment & 3.80 & .57 & -.11 & -.11 & .10 & .26 & .20 & -.01 & -.08 & .11 & .40 & -.01 & -.17 & -.18 & .45 & $(.77)$ & & \\
\hline 15. Turnover intent. & 2.81 & .87 & -.03 & -.07 & -.16 & -.15 & -.01 & .07 & -.15 & -.01 & -.38 & .25 & .20 & .28 & -.39 & -.17 & (.63) & \\
\hline 16. Job search & 2.41 & .91 & -.10 & -.10 & -.02 & -.15 & -.01 & .13 & .23 & .15 & -.42 & .34 & .37 & .54 & -.33 & -.38 & .32 & (.90) \\
\hline 17. Actual turnover & .06 & .24 & .01 & .04 & -.08 & -.11 & .21 & -.09 & .10 & -.17 & -.15 & .02 & .05 & .21 & - & - & - & - \\
\hline
\end{tabular}

Note. Indices in bold indicate that the correlation is significant at $p<.05$. 
Table 2

Goodness-of-fit indices for the measurement models at Time 1 and Time 2.

\begin{tabular}{|c|c|c|c|c|c|c|c|c|c|c|c|c|}
\hline Model & $\chi^{2}$ & $d f$ & $p$ & $\chi^{2} / d f$ & SRMR & RMSEA & IFI & CFI & Model comparison & $\Delta \chi^{2}$ & $\Delta d f$ & $p$ \\
\hline \multicolumn{13}{|l|}{ Measurement models } \\
\hline 1: Time 1 & 160.45 & 93 & .00 & 1.73 & .06 & .06 & .96 & .96 & & & & \\
\hline 2: Time 2 & 61.26 & 49 & .11 & 1.25 & .06 & .05 & .98 & .98 & & & & \\
\hline \multicolumn{13}{|c|}{ Model A: predicting loyalty and prepared exit at Time $2(n=99)$} \\
\hline $1_{\mathrm{A}}:$ Saturated/full model & 82.13 & 61 & .04 & 1.35 & .07 & .06 & .95 & .94 & & & & \\
\hline $2_{\mathrm{A}}:$ Saturated model adjusted & 77.61 & 68 & .20 & 1.14 & .07 & .04 & .98 & .97 & & & & \\
\hline $3_{\mathrm{A}}:$ Direct only model & 153.78 & 78 & .00 & 1.97 & .13 & .10 & .80 & .78 & M. $3_{\mathrm{A}}-\mathrm{M} \cdot 2_{\mathrm{A}}$ & 76.16 & 10 & $<.01$ \\
\hline $4_{\mathrm{A}}:$ Proposed indirect model & 90.35 & 76 & .12 & 1.19 & .07 & .04 & .96 & .96 & M. $4_{\mathrm{A}}-\mathrm{M} \cdot 2_{\mathrm{A}}$ & 12.74 & 12 & .39 \\
\hline \multicolumn{13}{|c|}{ Model B: predicting actual turnover at Time $2(n=210)$} \\
\hline $1_{\mathrm{B}}:$ Saturated/full model & 61.87 & 38 & .01 & 1.63 & .06 & .05 & .95 & .95 & & & & \\
\hline $2_{\mathrm{B}}$ : Saturated model adjusted & 54.59 & 42 & .09 & 1.30 & .05 & .04 & .97 & .97 & & & & \\
\hline $3_{\mathrm{B}}$ : Direct only model & 116.66 & 50 & .00 & 2.33 & .08 & .08 & .86 & .85 & M. $3_{B}-M .2_{B}$ & 62.07 & 8 & $<.01$ \\
\hline $4_{\mathrm{B}}:$ Proposed indirect model & 62.02 & 47 & .07 & 1.32 & .05 & .04 & .97 & .97 & M. $4_{\mathrm{B}}-\mathrm{M} .2_{\mathrm{B}}$ & 7.43 & 5 & .19 \\
\hline
\end{tabular}

Note. SRMR = Standardized Root-Mean-square Residual; RMSEA = Root Mean Square Error of Approximation; IFI = Incremental Fit Index; CFI = Comparative Fit Index. Good fit is indicated by a SRMR $\leq .08$, a RMSEA $\leq .06$, and IFI and CFI $\geq .95$ (Hu \& Bentler, 1999).

redundancy $(\beta=.08$, Sobel $=2.12, \mathrm{p}=.03)$ on actual turnover at Time 2 . The significant links from redundancy to loyalty ( $\beta=$ -.21 , Sobel $=-2.35, \mathrm{p}=.02)$ and exit intentions $(\beta=.26$, Sobel $=2.47, \mathrm{p}=.01)$ are only indirect, given that the direct model had not shown any significant relationships between these variables (Mathieu \& Taylor, 2006). No indirect effects emerged for job insecurity or via career planning $(\beta=-.01$ to .06 , Sobel $=.42$ to $1.47, \mathrm{p}>.10)$.

\section{Discussion}

This is one of the very few studies studying employees' behavior during organizational restructuring from a careersperspective. This perspective is not only valuable given the impact of organizational decisions on individuals' careers (e.g., Hall, 2004), but also in explaining outcomes relevant for both employees and organizations. Prior research showed that organizational turbulence and job insecurity foster loyalty towards one's career as opposed to one's organization (King, 2000; Reilly, Brett, \& Stroh, 1993). Yet, loyalty alone does not explain what individuals do. Career adaptability reflects peoples' free agency to take responsibility for their careers and exploration allows people to broaden their horizon of possible opportunities (Hall, 1986; Smart \& Peterson, 1997; Zikic \& Hall, 2009). This is also relevant for the employing organization: The more career exploration employees undertook, the lower loyalty and higher likelihood of exit they showed later.

The current data also support untested theory about external and self-initiated motivators of career adaptability (Blustein, 1988, 1997; Blustein \& Phillips, 1988; Zikic \& Hall, 2009): career exploration was high particularly among redundant and dissatisfied employees. A looming job loss seriously threatens employees' current status. It forces them to consider their situation and potential options. Regarding satisfaction, career exploration accounted for the links to loyalty and exit reactions five months later. Dissatisfied employees proactively thought about their own interests, and aspirations, and their options of changing jobs or employers (e.g., Zikic \& Hall, 2009). This in turn related negatively to employees' loyalty and positively to their intended and actual exit five months later. These findings attest to career exploration as a possibly self-initiated activity (Zikic \& Hall, 2009) and to the relevance of career adaptability for both individuals and organizations.

Reversely, low career exploration might explain the high loyalty of satisfied and of long-tenured employees. Particularly environmental exploration was generally low in the current sample, but was even lower among satisfied and long-tenured employees. Satisfied employees may work in a comfort zone that does not force them to think of alternatives and long-tenured employees were socialized into an organization valuing stability (e.g., Lippmann, 2008; Zikic \& Hall, 2009). Yet, low career exploration and anticipation of change can backfire as soon as employees face a need to change to other employment relationships (e.g., Hall, 1986).

Career planning was primarily initiated by redundancy and was inhibited by participants' job-insecurity, suggesting that worries about their jobs inhibited the planning of future career goals. This negative relationship concurs with earlier findings about impaired physical and mental wellbeing, attitudes and intentions towards the organization in response to job insecurity (Sverke et al., 2002). Given that planning is a hallmark of success in general and that career planning in particular predicts career success (Abele \& Wiese, 2008; Seibert et al., 1999), our results suggest that job insecurity may also impair workers' career success.

\section{Implications}

The current results bear implications for managers, employees, and outplacement programs. The results call managers to tell employees about a possible job loss early in advance instead of leaving them caught up in an unclear and insecure situation. Informing employees about their likely redundancy is a difficult task that managers may try to avoid. Such hesitance, however, can 


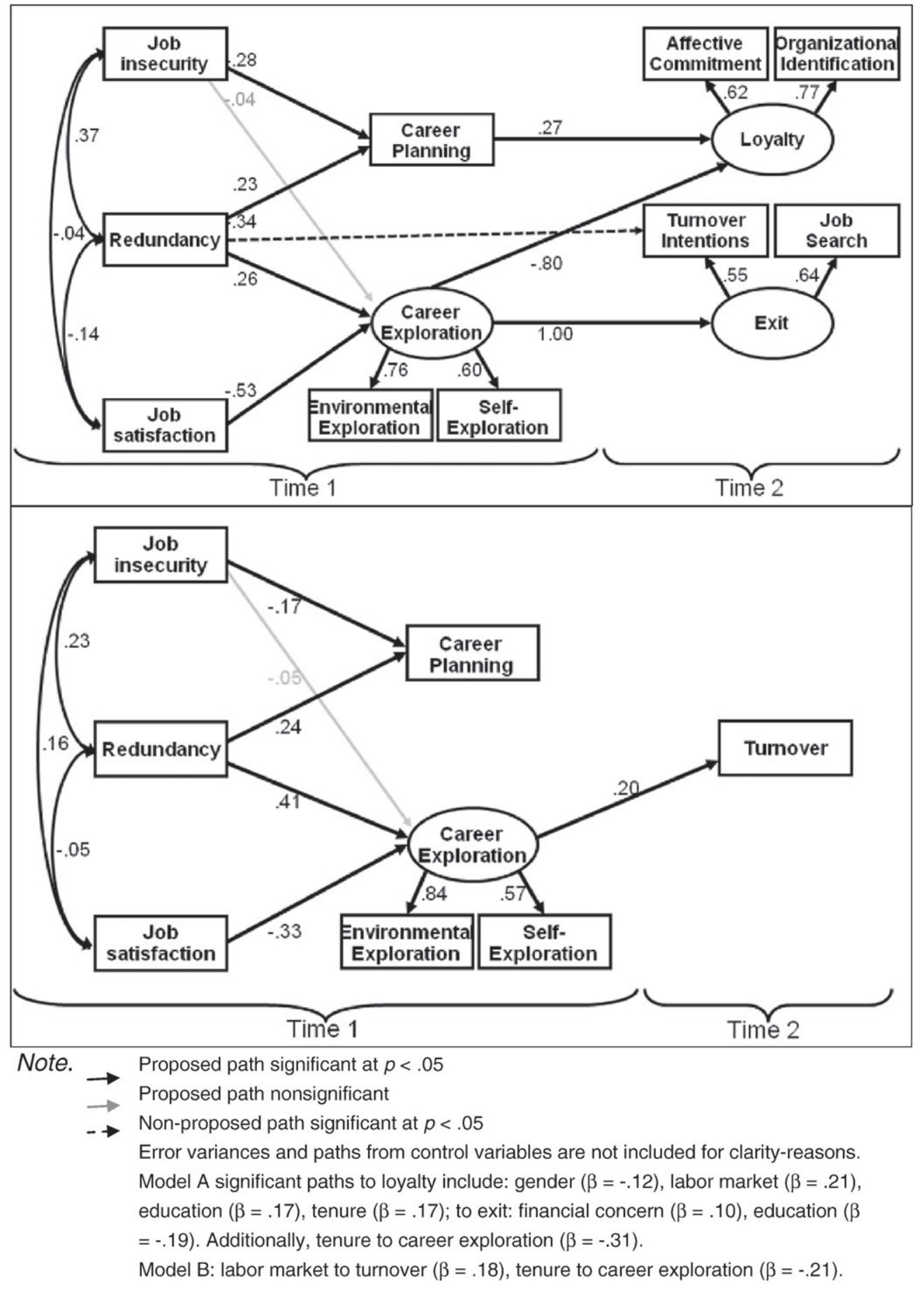

Fig. 2. Resulting Model. Top: Model A predicting loyalty exit considerations. Bottom: Model B predicting actual turnover.

cause prolonged insecurity among employees, resulting in numerous negative consequences (Sverke et al., 2002). While participants who knew that their jobs were redundant engaged in more adaptive career planning and exploration, prolonged worries about an uncertain future showed a rather contrary effect. Credibly reducing such by increasing transparency, predictability, and employee voice, should be a prime objective of organizational decision makers.

In practice, managers may also hesitate to allow redundant employees to remain in the organization for long out of fear that redundant employees may show counterproductive work behaviors and/or may negatively influence the morale of the surviving 
workforce. Yet, the current results suggest that employees' redundancy-status was nearly unrelated to their organizational loyalty. Additionally, a longer time period available to employees in order to prepare for their eventual job loss can signal to downsizing victims and survivors alike that the organization cares for its employees, thus reducing worries and distrust among organizational members.

Career planning and exploration are usually beneficial for displaced workers (Koen et al., 2010; Zikic \& Klehe, 2006; Zikic \& Richardson, 2007), but they can be difficult for employees who previously relied on a stable relationship with their current employer and who may find themselves entangled in a certain career routine (Hall, 1986; Lippmann, 2008). Also, past research suggests that many employees undergo a series of difficult stages following announced redundancy before they can actively cope with their situation (Lazarus \& Folkman, 1984). A longer phase between announcement and layoff allows affected employees sufficient time to consider their interests and options. As the current results show, being declared redundant a good year before the actual layoff did not delay participants from reacting to the situation. They still engaged in career planning and exploration. Additionally, these employees can use their remaining time in the organization to apply for alternative employment elsewhere without the stigma of unemployment attached to their vita and job-search. We further found that long tenured employees in particular scored low on career exploration. For outplacement programs, this implies that long-tenured employees may need more time and more assistance in undertaking such exploration.

\section{Limitations and directions for future research}

Employees' perceptions and plans are best examined by employees themselves. Yet, self-reports run the risk of common method bias (Podsakoff, MacKenzie, Lee, \& Podsakoff, 2003). In the current study, this appears to have been no major issue, given the five-month time-lag between assessments and the fact that correlations between distinct Time 1 variables were generally small and objective data (demographics, Time 1 redundancy, Time 2 exit) showed comparable correlations (Spector, 2006).

Second, while two measurement points are better than the cross-sectional design used in most job insecurity studies, such design cannot irrevocably prove the causal relations proposed. However, some effects are unlikely to find alternative explanations, given that they include objective data (redundancy, turnover) or were assessed over a five-month time-lag. Finally, a reversed order of predictors and career adaptability is unlikely since this would require the direct effects of, for example, job satisfaction on loyalty and exit to remain significant after accounting for career adaptability. Instead, career exploration fully mediated these significant direct effects. In order to understand the dynamic development of career-related coping during downsizing, we would suggest the use of more measurement points to test how predictors, such as job insecurity, processes, such as career activities, and outcomes, such as loyalty may change over time.

Third, due to difficulties in collecting longitudinal data during organizational restructurings, Model A relied on a relatively small sample size. Classic test theory implies this to be a concern in the case of non-supported hypotheses, yet our data supported most proposed relationships. Additionally, chosen test statistics are rather immune to small sample sizes while being sensitive to model misspecifications (Hu \& Bentler, 1999). Finally, findings in Model A mirror those in Model B on actual turnover, with Model B relying on a much larger sample.

Finally, findings may not generalize across economic times or to employees in less stable working agreements (Lippmann, 2008) than with a former life-time employer. Also, our data did not allow us to address differences in the delivery of the downsizing, whether it is across organizations or across different supervisors within the current organization. A different handling of the downsizing situation and particularly variance in procedural justice will likely show a meaningful impact not only on employees' eventual exit and loyalty reactions (e.g., Turnley \& Feldman, 1999), but also on employees' exploration and planning throughout the process. In addition, research might also test whether effects are moderated by individual characteristics, such, as proactivity, and whether the negative effects of job insecurity on career planning translate into poorer career success in different types of work arrangements.

\section{Conclusions}

The current paper addressed employees' reactions to organizational downsizing from a careers-perspective. We found that redundancy and low satisfaction can trigger employees' career adaptability, whereas job insecurity inhibits an adaptive response. Career adaptability, in turn, can work as a useful coping mechanism for individuals in such situations - at least when considered from an individual, not necessarily an organizational perspective. Particularly career exploration reduced employees' loyalty and fostered their exit from the organization.

\section{References}

Abele, A. E., \& Wiese, B. S. (2008). The nomological network of self-management strategies and career success. Journal of Occupational and Organizational Psychology, 81, 733-749.

Allen, N. J., \& Meyer, J. P. (1996). Affective, continuance, and normative commitment to the organization: An examination of construct validity. Journal of Vocational Behavior, 49, 252-276.

Anderson, C., \& Galinsky, A. D. (2006). Power, optimism, and risk-taking. European Journal of Social Psychology, 36, 511-536.

Armstrong-Stassen, M. (2002). Designated redundant but escaping lay-off: A special group of layoff survivors. Journal of Occupational and Organizational Psychology, 75, 1-13.

Ashford, S. J., Lee, C., \& Bobko, P. (1989). Content, causes, and consequences of job insecurity - A theory-based measure and substantive test. Academy of Management Journal, 32, 803-829.

Ashforth, B. E., \& Mael, F. (1989). Social identity theory and the organization. Academy of Management Review, 14, 20-39. 
Ashforth, B. E., \& Saks, A. M. (1995). Work-role transitions - A longitudinal examination of the Nicholson model. Journal of Occupational and Organizational Psychology, 68, 157-175.

Blau, G. (1994). Testing a two-dimensional measure of job search behavior. Organizational Behavior and Human Decision Processes, 59, 288 -312.

Blustein, D. L. (1988). The relationship between motivational processes and career exploration. Journal of Vocational Behavior, 32, $345-357$.

Blustein, D. L. (1997). A context-rich perspective of career exploration across the life roles. Career Development Quarterly, 45, 260-274.

Blustein, D. L., \& Phillips, S. D. (1988). Individual and contextual factors in career exploration. Journal of Vocational Behavior, 33, $203-216$.

Bridges, W. (1994). Job shift: How to prosper in a workplace without jobs. Addison-Wesley: Reading, MA.

Cameron, K., Freeman, S., \& Mishra, A. (1991). Best practices in white-collar downsizing: Managing contradictions. Academy of Management Executive, 5 , $57-73$. Cappelli, P. (1999). The new deal at work: Managing the market-driven workforce. Boston, MA: Harvard Business School Press.

Cascio, W. F. (1993). Downsizing: What do we know? What have we learned? Academy of Management Executive, 7, $95-103$.

Cascio, W. F. (2002). Strategies for responsible restructuring. Academy of Management Executive, 16, 80-91.

Cascio, W. F., \& Wynn, P. (2004). Managing a downsizing process. Human Resource Management, 43, 425-436.

Cascio, W. F., Young, C. E., \& Morris, J. R. (1997). Financial consequences of employment-change decisions in major US corporations. Academy of Management Journal, 40, 1175-1189.

Davy, J. A., Kinicki, A., \& Scheck, C. L. (1997). A test of job security's direct and mediated effects on withdrawal cognitions. Journal of Organizational Behavior, 18, $323-349$.

De Witte, H. (1999). Job insecurity and psychological well-being: Review of the literature and exploration of some unresolved issues. European Journal of Work and Organizational Psychology, 8, 155-177.

De Witte, H., \& Näswall, K. (2003). Objective vs subjective job insecurity: Consequences of temporary work for job satisfaction and organizational commitment in four European countries. Economic and Industrial Democracy, 24, 149-188.

Ferman, I., \& Aiken, M. (1964). The adjustment of older workers to job displacement. In A. Shostak \& W. Gomberg (Eds.), Blue-collar world (pp. 493-498). Englewood Cliffs. NJ: Prentice-Hall.

Flum, H., \& Blustein, D. L. (2000). Reinvigorating the study of vocational exploration: A framework for research. Journal of Vocational Behavior, 56, 380-404.

Galinsky, A. D., Gruenfeld, D. H., \& Magee, J. C. (2003). From power to action. Journal of Personality and Social Psychology, 85, $453-466$.

Gerbing, D. W., \& Anderson, J. C. (1985). The effects of sampling error and model characteristics on parameter estimation for maximum likelihood confirmatory factor analysis. Multivariate Behavioral Research, 20, 255-271.

Gilboa, S., Shirom, A., Fried, Y., \& Cooper, C. (2008). A meta-analysis of work demand stressors and job performance: Examining main and moderating effects. Personnel Psychology, 61, 227-271.

Gould, S. (1979). Characteristics of career planners in upwardly mobile occupations. Academy of Management Journal, 22, 539-550.

Griffeth, R. W., Hom, P. W., \& Gaertner, S. (2000). A meta-analysis of antecedents and correlates of employee turnover: Update, moderator tests, and research implications for the next millennium. Journal of Management, 26, 463-488.

Hagtvet, K. A., \& Nasser, F. M. (2004). How well do item parcels represent conceptually defined latent constructs? A two-facet approach. Structural Equation Modeling - A Multidisciplinary Journal, 11, 168-193.

Hall, D. T. (1986). Breaking career routines: Midcareer choice and identity development. In D. T. Hall (Ed.), Career development in organizations (pp. 120-159). San Francisco, CA: Jossey-Bass.

Hall, D. T. (2004). The protean career: A quarter-century journey. Journal of Vocational Behavior, 65, 1-13.

Hellgren, J., Sverke, M., \& Isaksson, K. (1999). A two dimensional approach to job insecurity: Consequences for employee attitudes and well being. European Journal of Work and Organizational Psychology, 8, 179-195.

Hu, L. -T., \& Bentler, P. M. (1999). Cutoff criteria for fit indices in covariance structure analysis: Conventional criteria versus new alternatives. Structural Equation Modeling, 6, 1-55.

Inkson, K., \& Arthur, M. B. (2001). How to be a successful career capitalist. Organizational Dynamics, 30, 48-61.

Jalonen, P., Virtanen, M., Vahtera, J., Elovainio, M., \& Kivimaki, M. (2006). Predictors of sustained organizational commitment among nurses with temporary job contracts. The Journal of Nursing Administration, 36, 268-276.

Kanfer, R., Wanberg, C. R., \& Kantrowitz, T. M. (2001). Job search and employment: A personality-motivational analysis and meta-analytic review. The Journal of Applied Psychology, 86, 837-855.

King, J. E. (2000). White-collar reactions to job insecurity and the role of the psychological contract: Implications for human resource management. Human Resource Management, 39, 79-91.

Kinnunen, U., Mauno, S., Natti, J., \& Happonen, M. (1999). Perceived job insecurity: A longitudinal study among Finish employees. European Journal of Work and Organizational Psychology, 8, 243-260.

Koen, J., Klehe, U. -C., Van Vianen, A. E. M., Zikic, J., \& Nauta, A. (2010). Job-search strategies and reemployment quality: The impact of career adaptability. Journal of Vocational Behavior, 77, 126-139.

Lammers, J., Galinsky, A. D., Gordijn, E. H., \& Otten, S. (2008). Illegitimacy moderates the effects of power on approach. Psychological Science, $19,558-564$.

Landy, F. J., \& Conte, J. M. (2004). Work in the 21st Century. An introduction to Industrial and Organizational Psychology. New York: McGraw-Hill.

Latack, J. C., \& Dozier, J. B. (1986). After the ax falls - Job loss as a career transition. Academy of Management Review, 11, $375-392$.

Lazarus, R. S., \& Folkman, S. (1984). Stress, appraisal, and coping. New York: Springer.

Lim, V. K. G. (1996). Job insecurity and its outcomes: Moderating effects of work-based and nonwork-based social support. Human Relations, $49,171-194$.

Lippmann, S. (2008). Rethinking risk in the new economy: Age and cohort effects on unemployment and re-employment. Human Relations, 61, $1259-1292$.

Locke, E. A., \& Latham, G. P. (1990). A theory of goal setting E' task performance. Prentice-Hall: Upper Saddle River, NJ, US.

Louis, M. R. (1980). Career transitions: Varieties and commonalities. Academy of Management Review, 5, 329-340.

Mael, F. A., \& Tetrick, L. E. (1992). Identifying organizational identification. Educational and Psychological Measurement, 52, $813-824$.

Mathieu, J. E., \& Taylor, S. R. (2006). Clarifying conditions and decision points for meditational type inferences in organizational behavior. Journal of Organizational Behavior, 27, 1031-1056.

Meyer, J. P., Allen, N. J., \& Smith, C. A. (1993). Commitment to organizations and occupations - Extension and test of a 3-component conceptualization. The Journal of Applied Psychology, 78, 538-551.

Miller, M. A., \& Rahe, R. H. (1997). Life changes scaling for the 1990s. Journal of Psychosomatic Research, 43, 279-292.

Parsons, F. (1909). Choosing a vocation. Boston: Houghton Mifflin.

Phillips, S. D. (1982). Career exploration in adulthood. Journal of Vocational Behavior, 20, 129-140.

Podsakoff, P. M., MacKenzie, S. B., Lee, J. Y., \& Podsakoff, N. P. (2003). Common method biases in behavioral research: A critical review of the literature and recommended remedies. The Journal of Applied Psychology, 88, 879-903.

Probst, T. M. (2003). Exploring employee outcomes of organizational restructuring - A Solomon four-group study. Group E Organization Management, 28, $416-439$.

Probst, T. M. (2005a). Countering the negative effects of job insecurity through participative decision making: Lessons from the demand-control model. Journal of Occupational Health Psychology, 10, 320-329.

Probst, T. M. (2005b). Economic stressors. In J. Barling, E. K. Kelloway \& M. R. Frone (Eds.), Handbook of work stress (pp. 267-297). Thousand Oaks: Sage.

Reilly, A. H., Brett, J. M., \& Stroh, L. K. (1993). The impact of corporate turbulence on managers attitudes. Strategic Management Journal, 14, 167-179.

Riketta, M. (2005). Organizational identification: A meta-analysis. Journal of Vocational Behavior, 66, 358-384.

Saks, A. M., \& Ashforth, B. E. (2002). Is job search related to employment quality? It all depends on the fit. The Journal of Applied Psychology, 87, 646-654.

Savickas, M. L. (1997). Career adaptability: An integrative construct for life-span, life-space theory. Career Development Quarterly, 45, $247-259$.

Savickas, M. L. (2005). The theory and practice of career construction. In S. D. Brown \& R. W. Lent (Eds.), Career development and counseling (pp. 42-70). Hoboken, New Jersey: John Wiley \& Sons, Inc. 
Seibert, S. E., Crant, J. M., \& Kraimer, M. L. (1999). Proactive personality and career success. The Journal of Applied Psychology, 84, $416-427$.

Shen, Y., \& Hall, D. T. (2009). When expatriates explore other options: Retaining talent through greater job embeddedness and repatriation adjustment. Human Resource Management, 48, 793-816.

Smart, R., \& Peterson, C. (1997). Super's career stages and the decision to change careers. Journal of Vocational Behavior, 51, $358-374$.

Smith, P. K., Jostmann, N. B., Galinsky, A. D., \& van Dijk, W. W. (2008). Lacking power impairs executive functions. Psychological Science, $19,441-447$.

Smith, P. C., Kendall, L. M., \& Hulin, C. L. (1969). The measurement of satisfaction in work and retirement. Chicago: Rand McNally.

Spector, P. E. (2006). Method variance in organizational research - Truth or urban legend? Organizational Research Methods, 9, 221 -232.

Stumpf, S. A., Colarelli, S. M., \& Hartman, K. (1983). Development of the career exploration survey (CES). Journal of Vocational Behavior, $22,191-226$.

Super, D. E., Savickas, M. L., \& Super, C. M. (1996). The life-span, life-space approach to careers. In D. Brown \& L. Brooks (Eds.), Career choice and development (pp. 121-178). San Francisco, CA: Jossey-Bass.

Sverke, M., \& Goslinga, S. (2003). The consequences of job insecurity for employers and unions: Exit, voice and loyalty. Economic and Industrial Democracy, 24, $241-270$.

Sverke, M., \& Hellgren, J. (2000). A review and meta-analysis of job insecurity and its outcomes. Work and Stress, 14, 189-190.

Sverke, M., \& Hellgren, J. (2001). Exit, voice and loyalty reactions to job insecurity in Sweden: Do unionized and non-unionized employees differ? British Journal of Industrial Relations, 39, 167-182.

Sverke, M., \& Hellgren, J. (2002). The nature of job insecurity: Understanding employment uncertainty on the brink of a new millennium. Applied Psychology-an International Review-Psychologie Appliquee-Revue Internationale, 51, 23-42.

Sverke, M., Hellgren, J., \& Näswall, K. (2002). No security: A meta-analysis and review of job insecurity and its consequences. Journal of Occupational Health Psychology, 7, 242-264.

Tett, R. P., \& Meyer, J. P. (1993). Job satisfaction, organizational commitment, turnover intention, and turnover-path analyses based on metaanalytic findings. Personnel Psychology, 46, 259-293.

Turnley, W. H., \& Feldman, D. C. (1999). The impact of psychological contract violations on exit, voice, loyalty, and neglect. Human Relations, $52,895-922$.

Wanberg, C. R., Hough, L. M., \& Song, Z. L. (2002). Predictive validity of a multidisciplinary model of reemployment success. The Journal of Applied Psychology, 87, $1100-1120$

Werbel, J. D. (2000). Relationships among career exploration, job search intensity, and job search effectiveness in graduating college students. Journal of Vocational Behavior, 57, 379-394.

Zikic, J., \& Hall, D. T. (2009). Toward a more complex view of career exploration. Career Development Quarterly, 58, $181-191$.

Zikic, J., \& Klehe, U. -C. (2006). Job loss as a blessing in disguise: The role of career exploration and career planning in predicting reemployment quality. Journal of Vocational Behavior, 69, 391-409.

Zikic, J., \& Richardson, J. (2007). Unlocking the careers of business professionals following job loss: Sensemaking and career exploration of older workers. Canadian Journal of Administrative Sciences-Revue Canadienne Des Sciences De L Administration, 24, 58-73. 